\title{
Half a Century of Tsetse and Animal Trypanosomosis Control on the Adamawa Plateau in Cameroon
}

\author{
A. Mamoudou ${ }^{1}$ A. Zoli ${ }^{1}$ P. Van den Bossche ${ }^{2}$ \\ V. Delespaux ${ }^{2}$ D. Cuisance ${ }^{3}$ S. Geerts ${ }^{2 *}$
}

Keywords

Cattle - Glossina - Trypanosomosis Insecticide - Insect control - Disease control - Cameroon.

\begin{abstract}
Summary
The invasion of tsetse flies into the Adamawa plateau occurred in the 1950s and resulted in high mortality in cattle due to trypanosomosis and massive emigration of livestock owners from the infested regions. Three species of tsetse flies have been recorded: Glossina morsitans submorsitans, G. fuscipes fuscipes and G. tachinoides. Between 1960 and 1975 the Cameroonian Government organized large-scale trypanocidal treatment campaigns of cattle. Later on, tsetse control activities were initiated. Between 1976 and 1994, several aerial spraying campaigns were carried out which resulted in the clearance of 3,200,000 hectares of pastures. Unfortunately, reinvasion of tsetse flies in several cleared areas could not be avoided. To prevent reinvasion of tsetse flies from Koutine Plain (north of the Adamawa plateau), a barrier consisting of screens and traps was set in place. However, bush fires destroyed most of the screens and traps soon after deployment in 1994. Thereafter, the barrier was replaced by a program of insecticide treatments of cattle. Cross-sectional and longitudinal parasitological and entomological surveys in 2004-05 showed that the barrier of insecticide-treated cattle had succeeded in keeping the plateau relatively tsetse free. The incidence of trypanosomosis in cattle on the plateau was reported to vary between 0 and $2.1 \%$. Recently, however, an alarmingly high prevalence of trypanocidal drug resistance was observed in the Faro and Deo division. Within the Pan-African Tsetse and Trypanosomosis Eradication Campaign (PATTEC), Cameroon is currently preparing a joint project with Chad, the Central African Republic and Nigeria to eradicate tsetse flies and trypanosomosis.
\end{abstract}

\section{INTRODUCTION}

The Adamawa plateau is located in the northern part of Cameroon; it covers more than $72,000 \mathrm{~km}^{2}$ and is one of the ten provinces of Cameroon. There are five subdivisions in the Adamawa province (Djerem, Faro and Deo, Mayo Banyo, Mbere, and Vina) (Figure 1).

\footnotetext{
1. University of Ngaoundéré, School of Medicine and Veterinary Sciences, Ngaoundéré, Cameroon.

2. Institute of Tropical Medicine, Animal Health Department, Nationalestraat 155, B-2000 Antwerp, Belgium

3. Gigean, France

* Corresponding Author

Tel.: +32 (0)3247 62 62; Fax: +32 (0)32476268

E-mail: sgeerts@itg.be
}

The rainy season lasts from March/April to October and most of the rainfall occurs between June and September. The Adamawa plateau is covered with savannah woodlands consisting of more than $90 \%$ of Daniellia oliveri and Lophira lanceolata (12). The most common grassland plants are Isoberlinia spp. and Sporobolus africanus (8). The environment is very suitable for intensive cattle rearing. The White Fulani or Akou and the Red Fulani or Djafoun are indigenous East African zebu breeds which arrived with transhumance and people immigration (2). The other breed known by its local name Gudali or Peul of Adamawa is an original breed of the province, more precisely from the Vina Division. The cattle are kept under traditional husbandry systems with communal herding. The husbandry practice is purely extensive with some public and private ranches. Occasionally, salt is offered to the animals. In the dry season many herds move (transhumance) from the plateau to the tsetse-infested valley (Koutine Plain). 


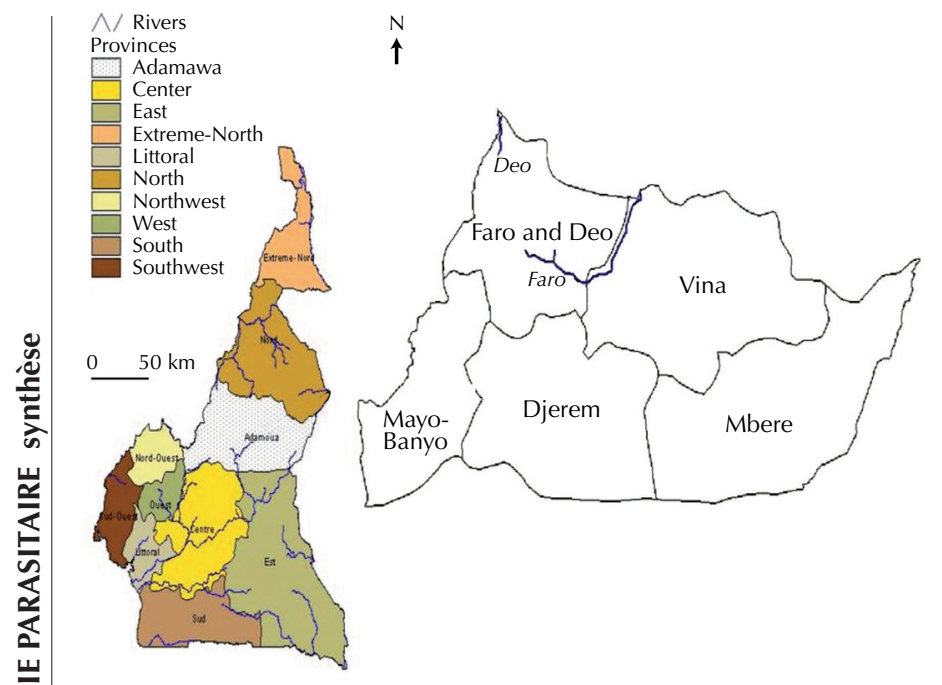

Figure 1: Map of the Adamawa province, Cameroon.

\section{INVASION OF THE ADAMAWA PLATEAU BY TSETSE FLIES}

The invasion - or increase in density - of Glossina morsitans submorsitans over the Adamawa plateau did occur around 1950 (Table I). Three species of tsetse flies have been recorded: Glossina $m$. submorsitans, $G$. fuscipes fuscipes and $G$. tachinoides $(1,10)$. At that time, about $40 \%$ of the national cattle herd was stocked on the Adamawa plateau (1). The important impact of this invasion by tsetse flies on the cattle industry is easily discernable. The disastrous effect of the infested areas on the economy was of course immediate and far reaching. Livestock owners suffered considerable losses when production parameters such as fertility, birth rate and weight gain dropped steadily while mortality rates rose in alarming proportions (1). Following this disastrous situation, there was massive emigration from the infested regions. This exodus created a communal disaster in the area. In Tignere, the most affected district, the cattle population dropped from 300,000 before the tsetse invasion to 35,000 (1). In the 1970 s, there were almost no cattle present anymore in Tignere area (3).

\section{Table I}

Key dates in the history of tsetse and trypanosomosis control in the Adamawa

\begin{tabular}{|c|c|}
\hline 1950 & Invasion of tsetse flies \\
\hline $1960-75$ & Mass treatment of cattle with trypanocides \\
\hline 1976-94 & Aerial spraying campaigns \\
\hline 1993-94 & Creation of a barrier against re-invasion \\
\hline Dec. 1994 & Bush fire destroys barrier \\
\hline 1995-present $(2009 \ldots)$ & Insecticide-treated cattle act as a barrier \\
\hline 2005 & $\begin{array}{l}\text { Alarmingly high level of trypanocidal } \\
\text { drug resistance reported }\end{array}$ \\
\hline 2009 & $\begin{array}{l}\text { Preparation of a regional program to } \\
\text { eradicate tsetse and trypanosomosis }\end{array}$ \\
\hline
\end{tabular}

\section{0-75: MASS TREATMENT CAMPAIGNS OF CATTLE WITH TRYPANOCIDES}

In order to control this disastrous situation, a biannual antitrypanosomosis campaign was instituted (from 1960 to 1975) by the government in the affected regions of the Adamawa and in the North and East Cameroon. These campaigns provided preventive treatment at the start of the transhumance and curative treatment upon return or in the case of illness (9). These mass treatments alone consumed an average of 600,000 doses of isometamidium chloride (Trypamidium ${ }^{\circledR}$, Rhone-Mérieux) (currently Merial) and 300,000 doses of diminazene aceturate (Berenil ${ }^{\circledR}$, Hoechst) annually (1). In 1967, with the objective of controlling the vectors of trypanosomosis, a tsetse control unit was created in the far northern part of the country. This unit launched a ground-spraying campaign with dichlorodiphenyl triclorethane (DDT) (1). Under the auspices of Lake Chad Basin Commission the operational capacities of the unit were intensified through a regional project between Cameroon and Nigeria (1970-1974). To reinforce the vector component of the fight against bovine trypanosomosis, the government created a specialized service in the Ministry of Livestock charged with tsetse eradication in 1974, the so-called 'Mission spéciale pour l'éradication des glossines' (MSEG or Special Unit for Tsetse Eradication). The unit headquarter was in the priority cattle production center of Ngaoundere in the Adamawa highlands.

\section{6-1994: LARGE-SCALE AERIAL SPRAYING CAMPAIGNS USING HELICOPTERS}

\section{Spraying campaigns}

The Adamawa highlands' campaign benefited from two years of entomological investigations before the spraying operations. Following the results of these entomological surveys, $8000 \mathrm{~km}^{2}$ of pastures were identified for helicopter spraying, but subsequent findings increased the area to about $10,000 \mathrm{~km}^{2}(1)$. The use of helicopters was necessary because of the broken inaccessible terrain. The first helicopter spraying campaign took place in the dry season 1976-77. During three campaigns since then an area of about $5700 \mathrm{~km}^{2}$ altogether was reclaimed. About $500 \mathrm{~km}^{2}$ out of this area were sprayed twice due to persistent fly pockets or re-invasion of tsetse (22). At the end of 1979, the area treated on the Adamawa plateau was about 10,000 km² (22). From 1977 until 1987, more than $21,000 \mathrm{~km}^{2}$ were treated with a total cost of 30,290,000 US\$ financed by the World Bank, FAO, the German Agency for Technical Cooperation (GTZ), and the Government of Cameroon (7).

Entomological surveys indicated a re-infestation of about 1000 $\mathrm{km}^{2}$ in $1988(4,5)$. Therefore, another aerial spraying campaign was launched in March 1989. The 1991 MSEG annual report confirmed the re-infestation of more than $3000 \mathrm{~km}^{2}$ in the Faro and Deo Division. In 1991-92 and 1994, two aerial spraying campaigns cleared more than $4000 \mathrm{~km}^{2}$ of the tsetse re-infested land (6). After eighteen years (1976-1994) of tsetse control activities using aerial spraying, 3,200,000 ha of pastures had been cleared (18). Three pyrethroids were used during these campaigns: Deltamethrin $\mathrm{ULV}^{\circledR}(3.2 \mathrm{~g} / \mathrm{L})$, Fendena $^{\circledR}$ (alphacypermethrin: $6 \mathrm{~g} / \mathrm{L}$ ) and Solfac ${ }^{\circledR}$ (cyfluthrin: $7.5 \mathrm{~g} / \mathrm{L}$ ). The only organochloride compound used was Thiodan $\mathrm{ULV}^{\circledR}$ (endosulfan: $25 \mathrm{~g} / \mathrm{L}$ ).

\section{Re-invasion of sprayed areas and tsetse dispersion}

In 1989, after fourteen years of aerial spraying campaigns, tsetse flies were cleared in the major part of the Adamawa plateau. However, in some areas re-invasion of tsetse was difficult to prevent because of the reasons described hereafter (5). 


\section{Access difficulty of some areas}

Some regions of the Adamawa plateau are difficult to access due to a network of rivers and ravines (58). Another factor, which affected the efficiency of the helicopter, is the hilly terrain in the Adamawa highlands. Numerous steep hills with deep river beds are difficult or dangerous to spray even with a helicopter. Furthermore, in order to avoid water pollution, insecticides were not sprayed near water courses (22). Finally, even when insecticides were applied, they did not always reach the resting sites of G. m. submorsitans.

\section{Persistence of the insecticides used}

In order to follow up the ecological recommendations and the limited choice imposed by the World Bank, four insecticide products were used separately or in association. However, due to the length of the rainy season in the Adamawa, the insecticides used should have had a persistence of at least two months (6). This was not always the case. Particularly with Solfac ${ }^{\circledR}$, tsetse flies were detected shortly after spraying (18), which meant that the adult fly population was probably decimated, but that there was a limited effect on the cohorts of flies which were present as pupae in the ground and which still had to emerge.

\section{Movement of cattle herds between infested and cleared areas}

Cattle markets and transhumance are potentially dangerous activities, which are not always compatible with the goal of tsetse eradication (5). Since there were a lot of commercial exchanges of cattle between the markets of Tchabal, Mbabo and Banyo, the cattle herds had to pass trough tsetse re-invaded zones which increased the risks of introducing tsetse flies into cleared zones (3). Similar risks are associated with the transhumance. At the beginning of the dry season the Ministry of Livestock, Fisheries and Animal Industries (MINEPIA) usually organizes the departure of the herds into transhumance from the cleared into the infested zone (Koutine Plain). Cattle are supposed to be treated with isometamidium before departure. The return of the herds takes place at a particular fixed date after the curative treatment of animals and compulsory individual spraying with Butox ${ }^{\circledR}$ at the post of Woulde or Sadeck (by MSEG staff). In 1990, however, because of the increasing pressure of tsetse during the end of the dry season and at the beginning of the rains, cattle owners liked to return faster and secretly (without insecticide treatment) from the infested plain to the plateau. This obviously resulted in the introduction of tsetse onto the plateau.

\section{Tsetse invasion via roads}

The road from Tignere to Kontcha constitutes "a privileged way" for tsetse to penetrate the cleared zone. This track is an important road in the dry season. It crosses the highly infested zone of Koutine Plain. The highest tsetse threat originates from the forest area where the flies have never been controlled and which borders the tsetse-infested game reserves of Faro $(2,6)$. Vehicles climb the cliff at a slow speed allowing tsetse to follow them (attraction by mobile objects) and to be carried into the cleared zone. In spite of limited resources, MSEG maintained the Sadeck checkpoint on top of the cliff where vehicles are inspected and sprayed (dieldrin) by two agents. Between 5 and 20 tsetse were caught every month on vehicles depending on the season, which is an indication of the potential role this road played in the re-invasion phenomenon (5). Rogers and Randolph (21) reported that, in theory, only one pregnant female tsetse needs to cross any barrier once to re-establish a population of flies. Sadeck and Garbaya checkpoints are separated by two river networks, one of which was highly infested. Forest galleries being very close, tsetse easily gained altitude, mainly where galleries were dense and water was abundant (5).

\section{Problems with re-invasion barriers}

Various methods can be employed to reduce the re-invasion of tsetse flies. In general, the aim of each tsetse control campaign should be to finish each phase at an easily defendable line (buffer zone or barrier), which may be either natural or man-made (23). A chronic lack of financial resources during the last four years of the program did not allow MSEG to play its role in clearing some re-invaded zones and in the protection of the clean zone against re-invasion $(4,5)$. Moreover, barriers can be made efficient, but can never guarantee total success against re-invasion; movements across barriers commonly occur and are frequently associated with animals, humans or vehicles (21).

\section{3-1994: CREATION OF A RE-INVASION BARRIER}

In 1990, Cuisance and Boutrais (6) proposed to combine the use of screens and traps barriers with insecticidal treatment of cattle herds in the buffer zone (Figure 2) as barriers against reinvasion from the north. However, the reduction of MSEG's funding did not allow the implementation of this recommendation until 1993. In 1993, with limited resources due to the suspension of an International Bank for Reconstruction and Development (BIRD) loan, a barrier was created on a small scale using 1014 screens impregnated with deltamethrin (28 March - 29 May 1993). Each of the three defense lines consisted of two rows (sometimes four) of screens impregnated with insecticides at an interval of 50-100 m. On each row, the screens were placed at $150 \mathrm{~m}$ interval. Inside each row, insecticide-impregnated biconical traps were added to reinforce the barriers (traps are more attractive than screens for some of the tsetse species present). From December 1993 onwards, about 3500 screens and 140 traps were progressively deployed along open tracks. In June 1994, sentinel traps were put in place and 23 fly rounds were organized in order to assess the efficacy of these barriers. To increase the efficiency of screens and traps two olfactory products (octenol and acetone) were used.

All screens and traps were impregnated with K-Othrin ${ }^{\circledR}$ (deltamethrin) by soaking and were retreated twice by pulverization

Game reserves $\quad \square$ Zones $\square$ Departments

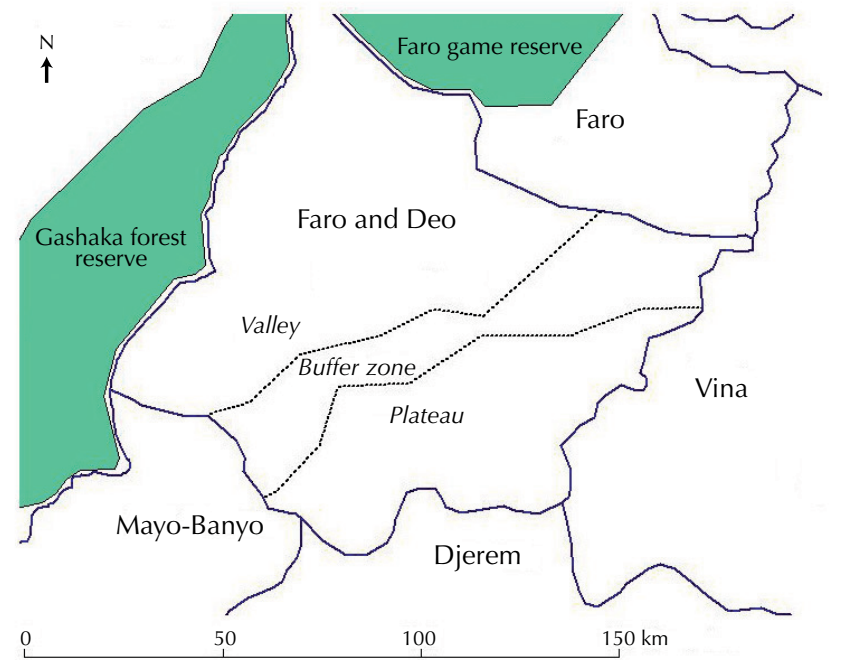

Figure 2: Map of the study area indicating the three zones (valley, buffer zone and plateau) of the Faro and Deo Division, Adamawa, Cameroon. 
between December 1993 and July 1994. Deployment of the barriers took almost one year (December 1993 to December 1994). According to Cuisance (5) the barriers were effective and played a non-negligible role in preventing re-invasion of tsetse. The efficacy of the barriers was confirmed by some livestock owners who stated that without the barriers livestock keeping would not be possible. Indeed, only one tsetse was found inside the barrier, while at a distance of some meters of the first rows of screens, many flies were captured (6).

Unfortunately, in the absence of local branches, MSEG had to manage the maintenance of this barrier from Ngaoundere, with a limited follow-up as a result (6). As a consequence, thefts and degradation of screens and traps were reported from 1993 onwards (18). In the absence of monitoring teams, clearing of the vegetation in the immediate surroundings of screens and traps was not conducted. In December 1994, about $90 \%$ of the barrier was destroyed by a bush fire during the dry season. The loss was estimated at about 28,300,000 FCFA (43,300 €). Besides economic losses, this massive destruction demoralized the senior staff and technicians who had worked hard to order the material, install it and make the barrier work efficiently (6).

\section{SITUATION AT THE END OF 1994}

At the end of the tsetse eradication campaigns in 1994, the territory was divided into the following three zones from South to North (Figure 2):

- the plateau, which was cleared of most tsetse flies (G. m. submorsitans) in 1994, with the exception of some small pockets. Large ranches with big cattle herds were present on the plateau. There was only limited transhumance to the tsetse-infested valley in the dry season and, if it occurred, often only involving part of the herds. Cattle were regularly dipped with insecticides during the rainy season;

- the buffer zone, designated by MSEG as a barrier to tsetse invasion from the valley to the Adamawa plateau (3). After the destruction of the screens and traps barrier it was advised that all stationary herds should be treated regularly with insecticides (pyrethroids). According to MSEG and the authors' observations, insecticides (sprays, pour-on applications for breeders, dipping for ranches) were used frequently although the treatment frequency varied according to the breeder's financial resources. Some treated all year round while others treated only during the dry or the rainy season. The most commonly used products were pyrethroids $\left(\right.$ Butox $^{\circledR}$, Cypermil $^{\circledR}$, Didétéki $^{\circledR}$, Ectopor $^{\circledR}$ and Eradick $\left.{ }^{\circledR}\right)$;

- the valley. Koutine Plain is an agricultural zone where the cattle keepers of the plateau and some herds from neighboring Nigeria spend the dry season (transhumance). The highest tsetse threat originates from the forest area where the flies have never been controlled. This forest area borders the tsetse-infested game reserves of Faro (3). In the West, the valley is bordered by the tsetse-infested Gashaga reserve forest in Nigeria (Figure 2). In 1994, G. m. submorsitans, G. fuscipes fuscipes and $G$. tachinoides were present in the valley. G. m. submorsitans was present in the buffer zone and on the plateau (6).

\section{$2004-2009$}

From 1994 until 2003 no entomological or parasitological surveys were carried out. In 2003, however, a project (funded by the Flemish Inter-University Council) was launched to assess the situation in the Faro and Deo division ten years after the end of the eradication campaigns. Cross-sectional and longitudinal entomological and parasitological surveys were carried out in the three zones of the study area (valley, buffer and plateau) during 2004-2005.

The results indicated that the monthly incidence of trypanosomosis on the plateau was still relatively low $(0-2.1 \%)$. This finding agrees with the observation that no tsetse flies were detected on the plateau. In the valley and the buffer zone, however, the trypanosomosis incidence varied between 3.7 and 20\%, and 1.8 and $13.4 \%$, respectively. Tsetse flies, mainly G. m. submorsitans and a few G. tachinoides were caught in the buffer zone and in the valley (15). These data clearly show that there is a significantly lower risk of infection on the plateau than in the buffer zone or the valley. This suggests that the impact of the tsetse eradication campaigns is still present.

More comprehensive entomological surveys in 2005 confirmed the absence of tsetse flies on the plateau, whereas G. m. submorsitans was present in the valley and the buffer zones, and G. tachinoides only in the valley (14). In the valley, the index of apparent abundance of tsetse flies was substantially higher in the areas close to the game reserves than in the transhumance area. In the transhumance area of the valley, the abundance of tsetse seemed to be associated with the presence of cattle with the highest index of apparent abundance recorded during the dry season when cattle were present and the lowest during the rainy season when cattle had moved onto the plateau. (14).

In 2005, the presence of trypanosome strains resistant to isometamidium chloride and diminazene aceturate was reported for the first time in Cameroon. Two different techniques were used: a field test (isometamidium-block treatment) and the standard mouse test (16). Later on, a survey using molecular tools to assess the prevalence of drug resistant trypanosome populations in cattle of the Faro and Deo Division showed that all of the 25 examined $T$. congolense isolates, and 3 out of $13 \mathrm{~T}$. brucei isolates were resistant to diminazene aceturate. Using the single dose mouse test, all of the 14 tested $T$. congolense isolates and 3 out of 13 T. brucei isolates were shown to be resistant to isometamidium. Resistance to both trypanocidal drugs is thus widespread in the study area (13). It remains to be examined, however, whether multiple drug resistance is present at the level of the cloned individual trypanosome.

The information collected between 2004 and today has important implications for managing the tsetse and trypanosomosis risk in the area. The following recommendations can therefore be made:

- the regular insecticide treatment of all cattle herds in the buffer zone should be continued to prevent re-invasion of the plateau by tsetse flies;

- a mandatory insecticide treatment scheme at the time of transhumance (which had been initiated by the Government long ago already) should be continued;

- sensitization campaigns should be organized to encourage livestock keepers to improve their tsetse control activities, to promote rational trypanocidal drug use and to apply correct dosages of trypanocides or seek appropriate support from professional veterinary services;

- to delay further development of drug resistance, the use of trypanocidal drugs on the plateau and in the buffer zone should be reduced as much as possible by avoiding mass treatments at the onset and at the end of transhumance and by limiting treatments to animals which really need it, i.e. sick and anemic $(\mathrm{PCV}<20)$ cattle;

- the quality of generic trypanocides available in the Adamawa should be controlled by the government. It is well known that substandard drugs which contain subtherapeutic concentrations of active ingredients contribute substantially to the development of drug resistance. 


\section{FUTURE PROSPECTS}

The Pan-African Tsetse and Trypanosomiasis Eradication Campaign (PATTEC) was launched in 2000 by the African Heads of States. The PATTEC action plan (11) seeks to apply area-wide principles to eliminate each pocket of tsetse infestation at a time. It would thus create a series of tsetse-free zones that can eventually be linked over a much larger area with the ultimate goal to eradicate tsetse from the African continent. Cameroon, in collaboration with Chad, the Central African Republic and Nigeria, is currently preparing a plan for a regional tsetse eradication program. The benefits of this large-scale control program are expected to be high for Cameroon and the region and may result eventually in a permanent solution for the tsetse and trypanosomosis problem on the Adamawa plateau.

\section{Acknowledgments}

This study was carried out with the financial support of the Flemish Interuniversity Council within the framework of a collaborative project between the University of Dschang, the University of Antwerp and the Institute of Tropical Medicine, Antwerp. We would like to thank Dr H. Hamadama, Head of MSEG, for providing research facilities.

\section{REFERENCES}

1. BANSER J.T., 1979. The evolution of tsetse and trypanosomiasis control in Cameroon. In: Proc. $16^{\text {th }}$ International Scientific Council for Trypanosomiasis Research and Control. Yaoundé, Cameroon, ISCTRC, p. 459-461.

2. BOUTRAIS J., 1978. Deux études sur l'élevage en zone tropicale humide (Cameroun). Paris, France, Orstom, 194 p. (Travaux et documents $n^{\circ} 88$ )

3. BOUTRAIS J., CUISANCE D., 1995. Les éleveurs de la zone tampon au nord de I'Adamaoua (Cameroun). Rapport de mission. Maisons-Alfort, France, Cirad-emvt, $59 \mathrm{p}$

4. CUISANCE D., 1989. La lutte contre les glossines dans l'Adamaoua (Cameroun). Compte-rendu de situation en février 1989 et propositions de programme. Maisons-Alfort, France, Cirad-lemvt, 33 p.

5. CUISANCE D., 1991. Lutte contre les glossines dans I'Adamaoua (Cameroun). Bilan de la situation et recommandations. Maisons-Alfort, France, Cirad-lemvt, 53 p.

6. CUISANCE D., BOUTRAIS J., 1995. Evaluation de la situation et de la stratégie de lutte contre les glossines et les trypanosomoses dans l'Adamaoua (Cameroun). Rapport de mission. Maisons-Alfort, France, Cirad-emvt, 63 p.

7. CUISANCE D., TACHER G., CLAIR M., NDOKI N.N.J., MULLER P., 1987. Lutte contre les glossines. Bilan et perspectives. Yaoundé, Cameroun, ministère de l'Elevage, des Pêches et Industries animales, 289 p. (CMR 85/004)

8. DE WISPELAERE G., 1994. Contribution of satellite remote sensing to the mapping of land use and of potential Glossina biotopes. Case study of the Adamawa plateaux in Cameroon. Rome, Italy, FAO, p. 74-89. (Animal production and health, No 121)

9. HAMADAMA H., 2001. Rapport sur la situation de la trypanosomose animale au Cameroun. In : FAO Réunion des coordinateurs chargés du contrôle de la trypanosomose africaine en Afrique centrale et en Afrique de I'Ouest, Ouagadougou, Burkina Faso. Rome, Italie, FAO.

10. HURAULT J. 1993. Comment a été vécue à Banyo et à Tibati la crise résultant de l'invasion des glossines (1990-1991). Rapport de mission. Yaoundé, Cameroun, Minepia, $53 \mathrm{p}$.

11. KABAYO J.P., 2002. Aiming to eliminate tsetse from Africa. Trends Parasitol., 18: 473-475.

12. LETOUZEY R., 1969. Etude phytogéographique du Cameroun. Paris, France, Le Chevalier, $513 \mathrm{p}$.

13. MAMOUDOU A., DELESPAUX V., CHEPNDA V., HACHIMOU Z., ANDRIKAYE J. P., ZOLI A., GEERTS S., 2008. Assessment of the occurrence of trypanocidal drug resistance in trypanosomes of naturally infected cattle in the Adamawa region of Cameroon using the standard mouse test and molecular tools. Acta Trop., 106: 115-118.

14. MAMOUDOU A., ZOLI A., HAMADAMA H., BOURDANNE, ABAH S., GEERTS S., ZESSIN K.-H., KYULE M., VAN DEN BOSSCHE P., 2008 Seasonal distribution and abundance of tsetse flies (Glossina spp.) in the Faro and Deo division of the Adamawa Plateau in Cameroon. Med. vet. Entomol., 22: 32-36.

15. MAMOUDOU A., ZOLI A., MBAHIN N., TANENBE C., BOURDANNE, CLAUSEN P.-H., MARCOTTY T., VAN DEN BOSSCHE P., GEERTS S., 2006. Prevalence and incidence of bovine trypanosomosis on the Adamawa plateau in Cameroon ten years after the tsetse eradication campaign. Vet. Parasitol., 142: 16-22.

16. MAMOUDOU A., ZOLI A., TANENBE C., ANDRIKAYE J.P. BOURDANNE, MARCOTTY T., DELESPAUX V., CLAUSEN P.-H., GEERTS S. 2006. Evaluation sur le terrain et sur souris de la résistance des trypanosomes des bovins du plateau de l'Adamaoua au Cameroun à l'acéturate de diminazène et au chlorure d'isométamidium. Revue Elev. Méd. vét. Pays trop., 59: 11-16.

17. MSEG, 1993. Annual report 1993. Ngaoundéré, Cameroun, Mission spéciale d'éradication des glossines, $38 \mathrm{p}$.

18. NDOKI J.J.W., 1994. Annual report 1994. Ngaoundéré, Cameroun, Mission spéciale d'éradication des glossines, 59 p.

19. PACE, 2005. Rapport du Programme national de contrôle des épizooties animales, délégation départementale du ministère de l'Elevage de Faro et Déo. Yaounde, Cameroon, Pan-African Programme for the Control of Epizootics, $18 \mathrm{p}$.

20. PNVRA, 2001. Rapport de la délégation départementale du ministère de I'Agriculture du Faro et Déo. Yaoundé, Cameroun, Projet national de vulgarisation agricole, $22 \mathrm{p}$.

21. ROGERS D.J., RANDOLPH S.E., 2002. A response to the aim of eradicating tsetse from Africa. Trends Parasitol., 18: 534-536.

22. SCHOLZ E., 1979. Tsetse fly eradication by means of helicopters in the Adamawa Highlands, Cameroon. In: $16^{\text {th }}$ International Scientific Counci for Trypanosomiasis Research and Control. Yaoundé, Cameroon, ISCTRC, p. 443-444.

23. WORLD BANK, 1987. The African trypanosomiasis methods and concepts of control and eradication in relation to development. Washington DC, USA, World Bank, 107 p. (Paper No 4)

Accepté le 16.02.2010 


\section{Résumé}

Mamoudou A., Zoli A., Van den Bossche P., Delespaux V., Cuisance D., Geerts S. Un demi-siècle de lutte contre la mouche tsé-tsé et les trypanosomoses animales sur le plateau de l'Adamaoua au Cameroun

L'invasion des glossines sur le plateau de l'Adamaoua se situe dans les années 1950 et a entrainé une mortalité élevée des à cause de la trypanosomose et des émigrations massives des éleveurs de la zone infestée. Trois espèces de mouches tsé-tsé ont été relevées: Glossina morsitans submorsitans, G. fuscipes fuscipes et G. tachinoides. Entre 1960 et 1975, le Gouvernement camerounais a organisé des campagnes de traitement aux trypanocides de masse du bétail. Des activités de lutte contre les glossines ont ensuite été initiées. Entre 1976 et 1994, plusieurs campagnes régulières de pulvérisation aérienne ont été réalisées aboutissant à l'assainissement de 3200000 hectares de pâturage. Malheureusement des réinvasions ponctuelles de la mouche tsé-tsé dans la zone assainie n'ont pas pu être évitées. Afin de prévenir la réinvasion des glossines à partir de la plaine de Koutine (au niveau du plateau de l'Adamaoua), des barrières constituées de pièges et d'écrans ont été créées. Cependant des feux de brousse ont détruit la plupart des piètes et de écrans peu après leur mise en place en 1994. Ils ont alors été remplacés par un programme de traitements insecticides du bétail. Des enquêtes transversales et longitudinales parasitologiques et entomologiques en 2004 et 2005 ont montré que la barrière constituée de bétail traité aux insecticides avait réussi à maintenir le plateau relativement indemne de glossines. L'incidence de la trypanosomose enregistrée chez le bétail du plateau variait entre 0 et 2,1 p. 100. Cependant une prévalence élevée inquiétante de résistance aux produits trypanocides a été rapportée récemment dans le département du Faro et Déo. Dans le cadre de la campagne panafricaine d'éradication des mouches tsétsé et des trypanosomoses (Pattec), le Cameroun est actuellement en train de préparer un projet commun avec le Tchad, la République d'Afrique centrale et le Nigeria pour éradiquer les mouches tsé-tsé et les trypanosomoses.

Mots-clés : Bovin - Glossina - Trypanosomose - Insecticide Lutte anti-insecte - Contrôle des maladies - Cameroun.

\section{Resumen}

Mamoudou A., Zoli A., Van den Bossche P., Delespaux V., Cuisance D., Geerts S. Medio siglo de control de la tse-tse y la tripanosomosis animal en la meseta de Adamaoua en Camerún

La invasión de las moscas tse-tse en la meseta de Adamaoua se dió en 1950 y resultó en una alta mortalidad de ganado debida a la tripanosomosis y a la emigración masiva de dueños de ganado de zonas infestadas. Se han registrado tres especies de moscas tse-tse: Glossina morsitans submorsitans, G. fuscipes fuscipes y G. tachinoides. Entre 1960 y 1975 el gobierno camerunés organizó, a gran escala, campañas de tratamiento tripanocida en el ganado. Luego, se iniciaron actividades para el control de la tse-tse. Entre 1976 y 1994, se llevaron a cabo varias campañas aéreas de rociado, las cuales resultaron en la limpieza de 3200000 ha de pastizales. Desafortunadamente, la reinvasión de moscas tse-tse en varias zonas limpias no pudo evitarse. Para prevenir la reinvasión de las moscas tse-tse desde la meseta de Koutine (norte de la meseta de Adamaoua), se puso en obra una barrera consistente de blancos y trampas. Sin embargo, fuegos forestales destruyeron la mayoría de los blancos y trampas poco tiempo después de ser puestos en 1994. Desde entonces, la barrera ha sido reemplazada por un programa de tratamientos insecticidas del ganado. Encuestas longitudinales y transversales, parasitológicas y entomológicas, entre 2004 y 2005, mostraron que la barrera de ganado tratado con insecticida ha logrado mantener la meseta relativamente libre de tse-tse. La incidencia de tripanosomosis en el ganado de la meseta fue reportada como variando entre 0 y $2,1 \%$. Sin embargo, recientemente se observó una prevalencia alarmantemente alta de resistencia a drogas tripanocidas en la división de Faro y Deo. En el seno de la Campaña pan africana de erradicación de la tripanosomosis y de la mosca tse-tse (PATTEC), Camerún está actualmente preparando un proyecto conjunto con Chad, la República Centroafricana y Nigeria, para erradicar las moscas tse-tse y la tripanosomosis.

Palabras clave: Ganado bovino - Glossina - Tripanosomosis Insecticida - Control de insecto - Control de enfermedades Camerún. 